\title{
Trade Regionalism, Decolonization-Bordering and the New Partnership for Africa’s Development
}

\author{
Johannes Tsheola \\ University of Limpopo, Polokwane, South Africa
}

\begin{abstract}
Theorization of region-border nexus affirms that regions are "contested contingent social constructs" established through bordering processes, whilst simultaneously symbolizing and institutionalizing borders. As a spatial process of bordering, trade regionalism should create and recreate "spaces of regionalism” for determination and dominion of territorial power over trade relations in the interest of decolonization, too. Africa's vertical trade relations with former colonial powers and increasingly with China have remained excessive under the New Partnership for Africa's Development (NEPAD), simultaneously as horizontal intra-African trade relations have become statistically meaningless. The Pearson's product-moment correlations and p-values for 2000 and 2006 inter-Regional Economic Communities (inter-RECs, including the rest of Africa) exports and imports show that NEPAD trade regionalism has failed to decolonize the meaning and function of colonial borders at the RECs spaces and continental scale, as an "act of reproducing territorial power" over which RECs and Africa could exercise dominion of trade relations.
\end{abstract}

Keywords: trade regionalism, decolonization, bordering, regional economic communities, NEPAD, product-moment correlation, Africa

\section{Introduction}

Theorization of region-border nexus affirms that regions are "social constructs that are contingent and contested” (Ramutsindela, 2011a, p. 1), and established through processes of bordering, in the process of which borders are "symbolized and institutionalized" (Jones, 2009; Jonas, 2011; Paasi, 2009a, 2009b; Ramutsindela, 2011a). Trade regionalism should be a deeply spatial process of bordering that holds the capacity to "redefine" the meaning and function of Africa's colonial borders (Ramutsindela, 2010a). Insights from the region-border studies suggest that trade regionalism should create and recreate regional spaces for the determination and domination of territorial power (Paasi, 2004, 2009b; Sidaway, 2002; Ramutsindela, 2009, 2010b, 2011a). Trade regionalism should be amenable to manipulation for shaping a regional space in accordance with specified goals of producing and reproducing dominion over trade relations (MacLeod \& Jones, 2007; Agnew, 2000; Paasi, 2010; Overman, Rice, \& Venables, 2010; Ramutsindela, 2011a). But the creation of spaces of trade regionalism does not automatically embed the "goodness" of decolonization.

The hegemonic market-integrationist conception and practice of trade regionalism have failed to give

Johannes Tsheola, Ph.D. in Geography, Senior Lecturer, Department of Development Planning \& Management, University of Limpopo.

Correspondence concerning this article should be addressed to Johannes Tsheola, P.O. Box 313, Fauna Park, 0787, South Africa. E-mail: johannes.tsheola@ul.ac.za. 
character to Africa's Regional Economic Communities (RECs) as regional trading spaces, identifiable through the form, direction, and significance of intra-bloc and extra-continental trade relations (Tsheola, 2010). Africa's vertical trade relations with former colonial powers (Gibb, 2009), and increasingly with China (Okoro \& Oyewole, 2011) have remained excessive under the New Partnership for Africa's Development (NEPAD), simultaneously as horizontal intra-African trade relations have become statistically meaningless. Decades of attempts to extricate Africa from external dominance through trade regionalism, progression towards more complex common markets, continental unity, and recently NEPAD has apparently failed to incubate decolonization. For this paper, the statistical strength and significance (credibility) of inter-RECs (including the rest of Africa (ROA)) trade relations in 2000 and 2006 should provide evidence whether NEPAD trade regionalism has transformed the meaning and function of colonial borders as an "act of reproducing territorial power” over which RECs and the ROA could exercise dominion of trade relations.

The intersection of regions and borders (Paasi, 2009b) affirms "how these two are involved in the process of co-production” (Ramutsindela, 2011a, p. 10). If states and other actors (forces) compete and/or collaborate in "shaping a regional space", then regions must also be central to non-spatial processes, in addition to their evident territoriality; and spaces of regionalism should therefore be territorial terrains for articulation and contestations of power and politics of engagement (Agnew, 2000; MacLeod \& Jones, 2007; Ramutsindela, 2011a). This paper holds that trade regionalism is intrinsically a bordering and socio-spatial process of transformation, which should be deliberately used to create and recreate "territorial power" as well as to produce and reproduce dominion thereupon (Paasi, 1999, 2004, 2005, 2009a, 2010; Sidaway, 2002; Ramutsindela, 2009, 2010b, 2011a, 2011b; Overman et al., 2010). Africa’s desire for decolonization through trade regionalism is longstanding and evident in initiatives such as the 1991 Treaty Establishing the African Economic Community (AEC), and recently NEPAD. Drawing from theorization of the region-border nexus, this paper argues that NEPAD trade regionalism bordering perpetuates neo-colonization of Africa by perpetuating vertical, above horizontal, trade relations. As a deliberate "bordering process", trade regionalism should transform the meaning and function of colonial borders as an "act of reproducing territorial power" over which RECs and the ROA could exercise dominion of trade relations. The next section draws insights from the theorization of region-border nexus in order to argue that Africa's trade regionalism is a bordering process that should facilitate socio-spatial transformation of the meaning and function of colonial borders in ways that promote horizontal, over vertical, trade relations.

\section{Region-Border Nexus: Trade Regionalism, Bordering and Territorial Power for Dominion of Trade Relations}

Two perspectives about regional bordering are broadly named relational and territorial approaches. Emphasizing economic experiences, the relational approach views regions as products of "interspatial relations, flows and networks” (Jonas, 2011, p. 1), devoid of territoriality and boundedness (Tuathail, 1999; Bathelt, 2006; Allen \& Cochrane, 2007; MacKinnon \& Tetzlaff, 2009; Ramutsindela, 2011a). Upholding territoriality of space, the territorial approach states that regions are made or unmade through complex processes, including that of bordering (Newman, 2006; Soderbaum \& Taylor, 2008; Jones, 2009; Paasi, 2009b; Darling, 2010; Jonas, 2011; Ramutsindela, 2011a). For this reason, borders are conceived as both "processes and institutions" (Newman, 2006; Paasi, 2009b; Ramutsindela, 2011a). Analysis of Africa's colonial bordering should show that the mere fact of excessive flows of capital and goods across state borders does not deterritorialize space, nor does it render territorial borders and power "uniformly less salient in the new world order" (Noe, 2010, p. 145). 
Inescapably, regions are both relational and territorial; therefore, regionalism involves interspatial relations and the process of bordering.

The colonial constructions of Africa for Europe's self-interests entailed the fragmentation of the African space into many weak countries with a serious potential for disastrous future decolonization (Ramutsindela, 1999). Two dominant perspectives on colonial bordering of African states are conveniently denoted “minimalist” and “extractive” (Anderson \& O’Dowd, 1999; Austin, 2008; Jones, 2009, 2010; Lefebvre, 2010; Jonas, 2011; Ramutsindela, 2010a, 2011a; Frankema, 2011). The minimalist perspective holds that the colonial state was created deliberately in order that it could perform "a minimum set of tasks at the minimum costs", whereas the "extractive" perspective suggests that it meant facilitating the exploitation of African resources through trade (Frankema, 2011, p. 137). Insights drawn from both perspectives should provide that Africa's decolonization remains "incomplete" because borders created for determination of colonial territorial power and external domination persist and continue to be recreated for reproduction of extraversion.

Importantly, Africa's colonial bordering involved a paradox that whereas colonial powers aspired towards regional constellations that amalgamated colonial states into regions of the empire, they instead established weak states with soft borders, apparently because of the poorly known, complicated and problematic environmental and geographical conditions (Newman, 2006; Austin, 2008; Bayart, 2009; Ginio \& Schler, 2010; Lefebvre, 2010; Ramutsindela, 2010a; Frankema, 2011). However, the creation of a weak state with soft colonial borders could have been a deliberate political choice because such a state would have, by definition, been "a prototype night watchman state" to be replaced later by regional constellations (Frankema, 2011, p. 137). For this and other reasons, Lefebvre (2010, p. 1) concluded that "African borders were drawn with rulers and coloured pencils on inaccurate maps by diplomats intoxicated by their sense of superiority”. This sense of power in colonial bordering meant that decolonization of Africa would be "unimaginable without reference to changes in either the physical lines dividing the continent or the functions of those lines, or both" (Ramutsindela, 2010a, p. 14). Whereas Africa's colonial bordering was neither arbitrary, "rationale choice” nor an "innocent exercise", "colonial powers had clearly articulated goals, namely, owning a piece of Africa and the wealth of the continent” (Ramutsindela, 2010a, p. 17). That is, the meaning and function of Africa's colonial borders were created and recreated as an "act of power" for specific objectives and strategies of “domination” (Newman, 2006; Paasi, 1999, 2005, 2009a, 2009b). Beyond just physical lines of separation, the non-physical presence of Africa's colonial borders attested to their construction and de-construction for the production and reproduction of "territorial power" (Ramutsindela, 1999, 2011a; Newman, 2006; Paasi, 2009a, 2009b; Fall, 2010; Noe, 2010; O’Dowd, 2010). For this reason, decolonization was never going to be a straightforward process (Ginio \& Schler, 2010).

Ginio and Schler (2010, p. 11) observed that processes of decolonization have "produced much complexity and uncertainty” wherein, simultaneously, there has been "rebirth”, “continuity”, "invalidation”, "exclusion and erasure". Ramutsindela (2010a) identified three propositions regarding the political ambition of Africa's decolonization and the future bordering as: (1) redrawing colonial borders in accordance with Africa's demography and other socio-cultural factors; (2) realigning colonial borders to "new" political ideals by means of regional integration; and (3) altering colonial borders in order to restore the bioregions, which coincidentally exist along or between international borders. The second proposition relates to trade regionalism as a bordering process for decolonization. In practice, Africa's “porous” colonial boundaries paradoxically afford greater potential for interaction, rather than serve as tools for genuine partition of the continental space (Ramutsindela, 
1999, 2010a, 2011a). Notwithstanding their fluidity and embodiment of "multiple meanings" over time (Ramutsindela, 2011a, p. 1), Africa's regions should also involve "processes that achieve their boundaries, symbolisms, and institutions in the process of institutionalisation” (Paasi, 2009b, p. 123). The ideal of Africa's decolonization could therefore be achieved by transforming the limiting character, rather than physical alterations, of the colonial borders (Anderson \& O’Dowd, 1999; Ramutsindela, 1999).

At the most, there are two broad perspectives on Africa's decolonization, named gradualism (regionalism) and radical continentalism (Sidaway, 2002; Ramutsindela, 2005, 2009, 2010a; Ginio \& Schler, 2010). The gradualist perspective proposes regionalism as a pragmatic approach and "platform on which the coalescence of state sovereignty" could be built first before being entrusted upon a continental entity in the long-run, whereas radical pan-Africanism espouses collapsing the whole continent into a single "borderless territory" with continental sovereignty performed from "one centre of power" (Ramutsindela, 2009, p. 1). The two perspectives are not mutually exclusive of each other because the fulcrum of their common denominator is in the transformation of the meaning and function of colonial borders and the creation and recreation of "territorial power” upon which Africa and/or its RECs could produce and reproduce dominion over regional activities, including trade. The distinction between the two perspectives runs a full circle because, given Africa's complex history and geography, neither of them can succeed without the other. For RECs trade bordering to be meaningful in cases where there exist regional relative superpowers that may act as bullies, the African Union (AU) will need to impose bordering through amalgamated continental jurisdiction over tariffs. Equally, the AEC vision will remain a pipedream if the RECs are not consolidated as regional trading spaces with meaningful discriminatory Common External Tariffs (CETs). History too shows that colonial regional borders were also tacitly reinforced through African trade, albeit informal, whilst power and dominion over the colonial regional trade space were ceded to former colonial interests.

Essentially, regions offer the opportunity for performing practical politics (Jones, 2009) of amalgamation of trade jurisdiction for decolonization. Such trade politics could be simultaneously exercised at both the RECs and continental scales, because bordering is contingent upon purpose across time and space. Region-border studies establish that colonialists attempted to "use borders in curving out regions by using individual colonies as stepping stones" because they were "not interested in small pockets of territories, and their conceptions of borders were influenced by their desire for creating larger territories than nation-states” (Ramutsindela, 2010a, p. 18). The Cecil John Rhodes’ vision of amalgamating British colonies from Cape to Cairo provides evidence that, "colonial borders were not designed to create nation-states but were, instead, part of a process of creating larger territories in the form of regions” (Ramutsindela, 2010a, p. 18). In this context, trade regionalism bordering has a potential for enforcing neo-colonization or decolonization. Setting up RECs through a meaningless CET wall, which allows for the persistence of vertical trade relations with the former colonial powers, may as well be strengthening a regional border that serves the purposes envisioned first through colonial bordering, rather than transforming its meaning and function for decolonization of trade. To this extent, trade regionalism is not an automatic or "innocent process" of decolonization. Indeed, "while regions are important for creating conditions for a decolonized Africa, they could also be used as a platform for neo-colonialism", because "former colonialists remain interested in the constellation of their former colonies" (Ramutsindela, 2010a, p. 23). The goal of establishing an AEC through NEPAD may as well be the pursuit of neo-colonization rather than decolonization. Trade regionalism, however, consists of a potentially meaningful decolonization bordering process because borders can deliberately be simultaneously "open and close", 
institutionalize "spatial and non-spatial qualities", and present "barriers and opportunities" (Agnew, 2008; Ramutsindela, 2011a). Perhaps, the question is whether Africa's trade regionalism used bordering for self-dominion of territorial power so created.

The multiplicity of trade regionalism schemes notwithstanding, five RECs adopted by the AU in 2002 as building blocks for the revival of the AEC vision come into sharp questioning under NEPAD's pluralistic trade regionalism approach. The AU had hoped to use NEPAD to renew the AEC continental integration vision by promoting intra-African trade relations among the Southern African Development Community (SADC), Common Market of Eastern and Southern Africa (COMESA), Economic Community of West African States (ECOWAS), Economic Community of Central African States (ECCAS), and the Arab Magreb Union (AMU) (Hugo \& Maloka, 2004; Tsheola, 2010), which relate loosely to five geographic regions of South, East, West, Central, and North Africa, respectively (see Figure 1). However, postcolonial exercise of regionalism has allowed for the establishment of "nominal trade regionalism", which undermined the decolonization-bordering properties of RECs (Bachmann \& Sidaway, 2010; Tsheola, 2010).

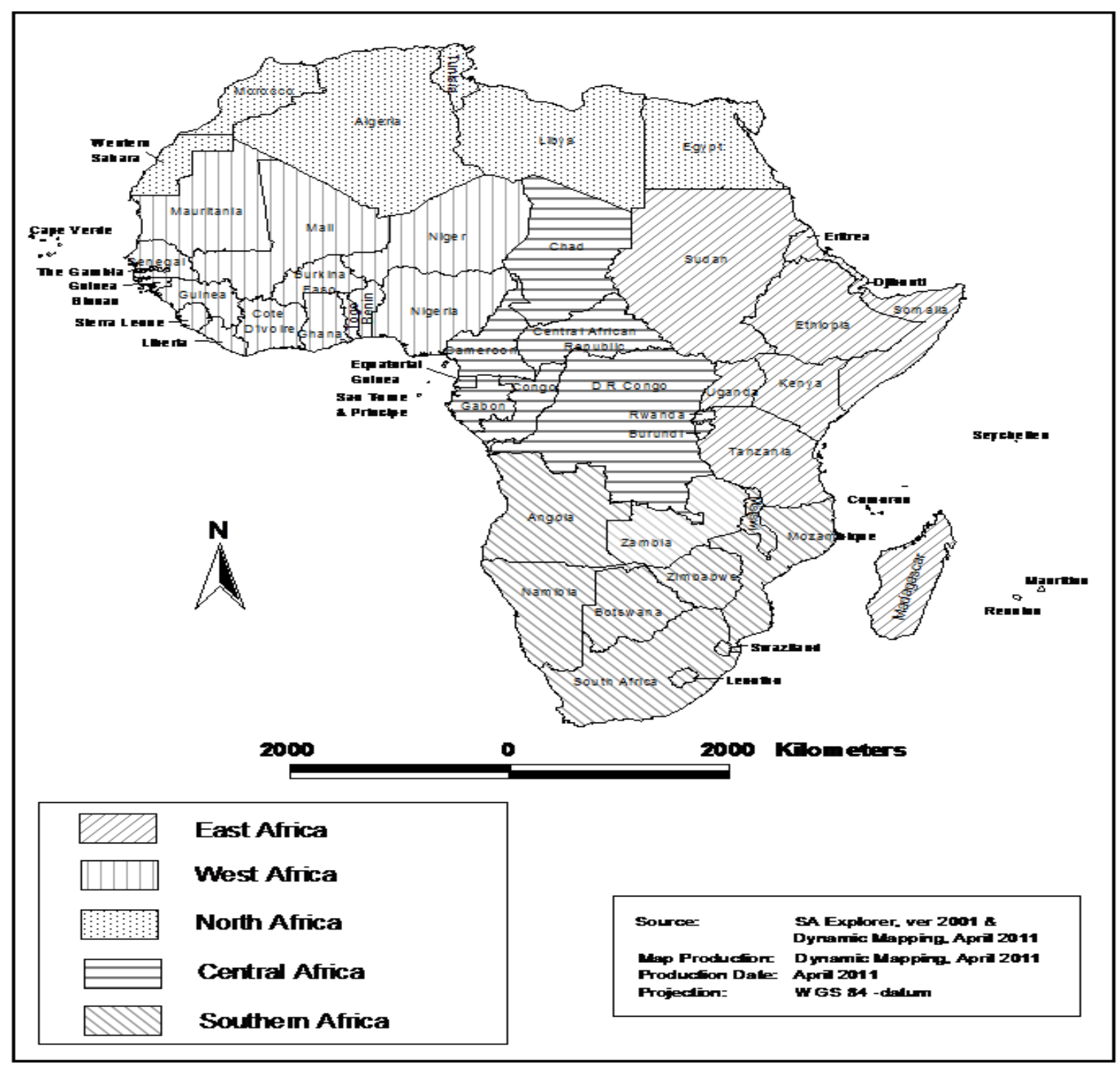

Figure 1. Map of Africa’s geographic regions. 
This paper argues that if borders and regions are linked conceptually as "mutually constitutive", albeit not “necessarily related in co-determining ways” (Ramutsindela, 2011a, p. 3), trade regionalism should ably transform Africa's trade structure to promote horizontal, above vertical, trade relations. As social constructs, regions can assume "different territorial status and meanings" (Ramutsindela, 2011a, p. 3). Spaces of regionalism, therefore, "demonstrate the role of the border in the evolution of regions", and "the presence of the border is a necessary condition for the creation of trans-border spaces and interactions” (Ramutsindela, 2011a, p. 3). To this extent, Africa and its RECs' bordering should become "narratives" through which trade regionalism is conceived and practiced for decolonization. Increased horizontal trade relations among African RECs and controlled vertical trade interactions with former colonial powers and China would be the clearest indicator of Africa's trade regionalism's decolonization-bordering. Given that Africa is riddled with skeletons of failed trade regionalism, how else would the continent achieve predominance of horizontal, over vertical, trade relations in the phase of hegemonic neoliberal globalization?

NEPAD trade regionalism decolonization ought to manifest in terms of its "bordering" as a "transformative" socio-spatial process that limits Africa's excessive vertical importation trade relations with former colonial powers and China. Perhaps, NEPAD is a return to an old colonial goal covered in nuance world commerce arguments, because the importation relations of some African countries from China provide strong evidence that its transformation of the meaning and function of borders could have merely been to deconcentrate vertical trade relations from west-dominion to east-orientation. The increased predominance of Chinese exportation to Africa compounds trade regionalism problems (Okoro \& Oyewole, 2011). For Africa's trade regionalism bordering to render regional borders meaningful and functional for decolonization, importations from China and elsewhere should be controlled, so that they may not be excessive, by instituting meaningful REC and ROA discriminatory CET walls. In this regard, NEPAD has failed to transform the RECs and continental trade structure for decolonization because it has perpetuated the extraversion of dominion over Africa's “territorial power". Rather than advocating severance of vertical trade relations with former colonial powers and China, this paper calls for context-specific balancing of pluralistic and amalgamation regionalism development processes in NEPAD and Africa's RECs. Africa's trade regionalism failed to counteract the divisive nature of the paradoxically "porous" colonial borders because the proliferation of regional integrative schemes was based on pluralism of jurisdiction (Njinkeu \& Fosso, 2006; Tsheola, 2010), which holds a neoliberal globalization assumption of a "borderless world" and free trade multilateralism.

\section{Amalgamated Versus Pluralistic Trade Regionalism: Whither NEPAD?}

Whereas Africa's vertical trade relations with the former colonial powers compound Africa's decolonization problems, severing them would equally deny the continent's opportunity to participate beneficially in the globalized economy (Okoro \& Oyewole, 2011). Broadly, trade regionalism development processes are divided into two approaches: pluralism and amalgamation of jurisdiction (Olivier, 2001). Pluralistic approach means that member states retain jurisdiction over their activities, including trade, whereas amalgamation involves collective jurisdiction by the supranational entity (Olivier, 2001). Under pluralistic trade regionalism it is virtually impossible for RECs to create intra-bloc trade expansion-friendly environment, which is a key prerequisite for inter-REC trade promotion. Regional provisions for enforcement of amalgamated jurisdiction over trade should be feasible for individual RECs, as targeted, step-by-step initiatives 
and stepping stones towards the attainment of the ideal of an amalgamated AEC trade jurisdiction in the long-run. Given that the five RECs "are in a pivotal position to play an intermediary role in a continent-wide revival” (Olivier, 2001, p. 43), amalgamation of trade jurisdiction should start with each of them. To promote inter-RECs (intra-African) trade relations, intra-RECs trade must first be consolidated and strengthened. To this extent, trade regionalism of each REC should involve bordering for amalgamated jurisdiction over trade with other RECs, the ROA and the rest of the world. Due to the absence of amalgamation of trade jurisdiction in NEPAD, Africa and its RECs trade regionalism bordering failed to transform the meaning and function of regional colonial borders with regard to horizontal intra-African trade goals and ideals.

By perpetuating the pluralistic trade relations, NEPAD itself undermines RECs' potential for decolonization. Unfettered pluralistic trade regionalism makes it impossible for RECs to establish "appropriate" CET walls as one of the instruments for amalgamated jurisdiction over trade. The notion of "non-discrimination, (and) treating virtually all countries equally" (Olanrewaju, 2007, p. 6) together with the General Agreement on Tariffs and Trade (GATT), now World Trade Organization (WTO), requirement that existing regional arrangements amounting to a departure from the Most Favoured Nation (MFN) principle would only be acceptable if "the tariff applying to external parties is not, on the whole, higher than the tariffs previously in force” (Davies, 1996, p. 34), enforce dangerously lower tariffs for African RECs because the majority of member states have previously adopted and applied several structural adjustment programmes (SAPs) (Tsheola, 2010).

NEPAD’s pluralistic trade regionalism trajectory has seen self-selecting member states such as South Africa and Libya individually entering into trade negotiations and arrangements with the European Union (EU), thereby rendering trade regionalism bordering of SADC and AMU, respectively, meaningless. Under NEPAD, neo-colonization of Africa has appeared to involve the predominance of the Sino-Africa trade relations wherein the value of importation from China to selected African countries, who are also economically strong members of RECs, increased sharply compared to their exportation to China (see Table 1). The value of China's exportation into Africa, under NEPAD, has remained multiple times greater than that of Africa's exports to China. For instance, despite South Africa's exports to China increasing 1,240 times and that for imports from China increasing 877 times between 1998 and 2006, the real trade values changed from US\$168.1 million to US\$854.6 million and from US\$2,085.1 million to US\$7,494.8 million, respectively, over the same period (see Table 1).

Okoro and Oyewole (2011, pp. 735, 736) showed that "China's exports to Africa have increased dramatically" since at least 2002, attaining an estimated "trading and investment” value of US\$55.5 billion in 2006. Whereas imports from China have always been higher than exports to China in 1998, the NEPAD-era has seen a dramatic general increase in Africa's importations from China. African countries whose exportation to China were larger than their importation from China involved oil and other natural resources that China pursued aggressively in Africa (Okoro \& Oyewole, 2011). China's exportation of large quantities into African markets suggests the latter's dependency on the former; and, this trade structure does not make for Africa's decolonization, unless if one seeks to suggest that one form of colonizing trade regionalism bordering could be better than another. By perpetuating this extraversion, NEPAD is rendering REC trade regionalism bordering a neo-colonization, if not meaningless process. 
Table 1

NEPAD-era African Exports to and Imports From China, 1998, 2002, \& 2006, in US\$ Million \& Index of $1998=100$

\begin{tabular}{|c|c|c|c|c|c|c|c|c|c|c|}
\hline \multirow{3}{*}{ Country } & \multicolumn{2}{|c|}{$\begin{array}{l}1998 \text { (Index: } \\
1998=100)\end{array}$} & \multicolumn{4}{|c|}{2002} & \multicolumn{4}{|c|}{2006} \\
\hline & \multirow{2}{*}{$\begin{array}{l}\text { African } \\
\text { Exports } \\
\text { Volume }\end{array}$} & \multirow{2}{*}{$\begin{array}{l}\text { Imports from } \\
\text { China } \\
\text { Volume }\end{array}$} & \multicolumn{2}{|c|}{ African Exports } & \multicolumn{2}{|c|}{$\begin{array}{l}\text { Imports from } \\
\text { China }\end{array}$} & \multicolumn{2}{|c|}{ African Exports } & \multicolumn{2}{|c|}{ Imports from China } \\
\hline & & & Volume & Index & Volume & Index & Volume & Index & Volume & Index \\
\hline Angola & 139.7 & 40.2 & 988.2 & 707.37 & 67.4 & 167.66 & $9,937.1$ & $7,113.17$ & 983.8 & $2,447.26$ \\
\hline Ethiopia & 0.7 & 67.5 & 7.4 & $1,057.14$ & 144.4 & 213.93 & 119.8 & $17,114.29$ & 474.8 & 703.41 \\
\hline Ghana & 7.7 & 122.5 & 27.4 & 355.84 & 200.5 & 163.67 & 72.6 & 942.86 & 883.2 & 720.98 \\
\hline Kenya & 1.3 & 68.3 & 4.7 & 361.54 & 76.8 & 112.45 & 22.1 & $1,700.00$ & 683.8 & $1,001.17$ \\
\hline Mozambique & 0.0 & 12.7 & 6.9 & 690.00 & 16.5 & 129.92 & 32.9 & $3,290.00$ & 76.5 & 602.36 \\
\hline Nigeria & 24.9 & 393.1 & 73.9 & 296.79 & 739.2 & 188.04 & 252.5 & $1,014.06$ & $3,141.2$ & 799.08 \\
\hline Senegal & 3.2 & 28.6 & 8.6 & 268.75 & 44.8 & 156.64 & 9.2 & 287.50 & 153.4 & 536.36 \\
\hline South Africa & 168.1 & 854.6 & 447.8 & 266.39 & $1,488.1$ & 174.13 & $2,085.1$ & $1,240.39$ & $7,494.8$ & 877.00 \\
\hline
\end{tabular}

Note. Source: Trade volumes drawn from Okoro and Oyewole (2011).

Pluralistic trade regionalism tends to strengthen the existing varieties of vertical trade linkages and identities that African countries hold largely with their former colonial powers (Makgetlaneng, 2004). Under NEPAD's pluralistic trade regionalism most states have remained "overwhelmingly geared towards trade with extra-continental markets" (Botha \& Aggad, 2004, p. 158). African RECs have become "rudimentary geographical trade configurations” (Olivier, 2001, p. 43) as member states' neo-colonial trade relations with extra-continental powers persist, because NEPAD "makes cross-border trade merely derivative from general trade liberalization" (Weeks, 1996, p. 105). Pluralistic trade regionalism is "methodologically and theoretically out of touch with the reality of African economic conditions" (Samasuwo, 2004, p. 149), where "African exports are not significant imports in African countries themselves" (Oyejide, 2000, p. 11). To consolidate Africa's RECs, "the first goal for a regional grouping should be to maximize intra-regional trade rather than trade with third-party countries at the expense of the region” (Ralinala, 2004, p. 131). NEPAD's pluralistic trade regionalism would not extricate Africa from the colonial bordering imposture because self-selecting states are free to individually and/or collectively adopt the MFN principle for global trade multilateralism and liberalization at the expense of amalgamation of trade regionalism jurisdiction.

\section{Pearson Product-Moment Correlation and $\boldsymbol{P}$-Value for Trade Relations}

Coefficient of determination or correlation is one of the simplest and most commonly used statistical techniques in spatially-oriented analyses largely because it is less discriminatory requiring fewer assumptions about the nature of the data, yet more robust (Haring \& Lounsbury, 1983; Edbon, 1985; Barber, 1988; Preece, 1994). This technique is frequently applied in geographic analyses because of its usefulness in measuring relative relationships among spatial units and affording the ability to predict the probability of the various patterns of occurrences (Mainardi, 2003; White, Tan, \& Hammond, 2006). The coefficient of determination measures the percentage of the total variation in "Y" explained statistically by the distribution of " $X$ "; and, the coefficient of correlation is the square root of the coefficient of determination. The technique provides a "valuable statistical procedure" especially where multiple correlations are inevitable due to the inability to 
control all factors that may have influence on the measure of performance being assessed (Preece, 1994, p. 166).

Pearson Product-Moment Correlation is a parametric statistic that provides a more accurate measure of coefficient of determination most widely used in spatially-oriented research. It is equally suited for use in simple correlation where there is one independent variable and in multiple correlations where there could be more than one independent variable. It could be used as a descriptive measure of the degree (strength and direction) of a relationship between variables, and as a measure of the linear relationship between variables or "the dispersion of points about the straight line" on the basis of the assumption that the form of the relationship is linear (Edbon, 1985, p. 97). In addition to scattergram plotting, the correlation output matrix is symmetric wherein "the correlation between two variables $\mathrm{X}$ and $\mathrm{Y}$ necessarily equals the correlation between variables $\mathrm{Y}$ and X", whilst the top-left to bottom-right diagonal values record correlations of 1.0 for the relationship of each observation with itself (Barber, 1988, p. 373). Whereas it requires that the data be measured on an interval scale and assumes that the variables are all drawn from normally distributed populations, product-moment correlation has proved valid and reliable in geographic analyses where most geographical data seldom meet this restrictive assumption. Pearson's correlation ranges between 0.0 and 1.0, where values approaching 0.0 signify weak relationships whereas those near 1.0 are indicative of very strong correlations. It is generally accepted that coefficients below 0.25 suggest that there is no meaningful relationship, those between 0.25 and 0.50 show minor to moderate relationships, those between 0.50 and 0.75 may be considered substantial depending on the nature of the investigation, whilst those above 0.75 are considered as high (strong) and those over 0.90 as very strong relationships.

Additionally, the two coefficients can be used in tests of significance of correlations through the PROB-VALUE or $p$-value (Edbon, 1985; Barber, 1988). Loosely, the $p$-value is interpreted in this paper as the degree of belief or credibility of the product-moment correlation of trade obtaining between RECs. Statistical significance indicates that whether an observed relationship or difference can be taken to signify anything else. Statistical tests of significance rely on the concept of probability; and, the $p$-value is helpful in setting the level of significance of the observed correlations and in providing the probability that a relationship is "significant". In this paper, the $p$-value is interpreted as the significance, confidence, or credibility of the inter-RECs (including ROA) trade relations. If the Pearson's coefficient occurs at the 0.01 level of confidence, it is considered to be "highly significant" because the odds are only one-in-a-100 that a relationship as high as the one found could be obtained by accident. The level of confidence commonly cited in social sciences is 0.05 , meaning that correlations are considered "significant" because a finding that five-in-a-100 odds that a high relationship such as the one observed could have occurred by accident should not be disastrous. This paper adopts the 0.05 confidence level for determination of statistical credibility of intra-African trade relations.

Factor analysis was used to generate Pearson's Product-Moment Correlation and $p$-value matrices from six-by-six raw data input matrices. The versatility and rigor of factor analysis as a multivariate statistical technique is attested to in a variety of studies (for example, Stambough \& Thorson, 1999; Mainardi, 2003; Lautre \& Fernandez, 2004; Ghosh \& De, 2005; Andoh, Umezaki, Nakamura, Kizuki, \& Takano, 2006; White, Tan, \& Hammond, 2006; Imoto, Yabuuchi, \& Watada, 2008; Torokhti \& Friedland, 2009). These studies affirmed the validity and reliability of applications of this technique in diverse multivariate analyses, including spatially-based data. A total of four raw data matrices, consisting of the US\$ volumes of "exports to" and "imports from" each of the five RECs and the ROA for 2000 and 2006, were analysed. Analysis of each raw 
data matrix generated a six-by-six correlation and $p$-value matrix. Whereas the Product-Moment Correlation does not show the dynamism of intra-African trade relations, it allows for their interpretations as meaningless, moderate, substantial, high, or very strong. Credibility of high or very strong correlations can then be established through the $0.05 p$-value. The change in the correlations as well as in the level of confidence in intra-African trade relations between 2000 and 2006 should, therefore, reveal whether inter-RECs (including ROA) trade relations have weakened or strengthened, and become insignificant or significant under NEPAD. If horizontal, rather than vertical, trade relations have become statistically dominant, the results should point to high and very strong correlations with $p$-values of 0.05 or less. In such a case, the conclusion would be reached that NEPAD is decolonizing Africa by increasingly transforming the meaning and function of colonial borders, allowing RECs and the ROA dominion over the "territorial trading power" created through regionalism.

\section{Intra-African Trade Relations, 2000 and 2006}

Analysis of the 2000 and 2006 inter-RECs trade (exports and imports) volumes, measured in terms of US\$, among the five RECs (including the ROA) recognized by AU provide for the correlations (strength and direction) and $p$-values (significance test) of intra-African trade relations before and after the adoption of NEPAD. Together with exports and imports from the ROA, the five RECs as places of origins and destinations allowed for a statistical possibility of 36 inter-African trade relations from each of the four input matrices. For intra-REC trade, which is presented in the input matrices as each REC's trade with itself, correlations of 1.0 are captured along diagonal cells from top-left to bottom-right of the output matrices. Additionally, this statistical modelling assumes correctly that trade relations between REC A and REC B are similar to those between REC $B$ and REC A, meaning that REC A's exports to REC B are also imports of the latter from the former. For these reasons, analysis of each of the four input matrices generates correlations and $p$-values for only 15 trade relations among the five RECs and the ROA. This discussion involves, therefore, a total of 30 trade relations, inclusive of exportations and importations, for each year of study.

Correlations are used to determine whether trade relations are meaningless (below 0.25), minor to moderate (0.25-0.50), substantial (0.50-0.75), high (0.75-0.90), or very strong (above 0.90$)$. The $p$-value of 0.05 is adopted to establish the level of confidence that the high and very strong inter-RECs trade relations, as observed, would not have occurred by accident. The statistical model shows that whereas 13 trade relations were high to very strong in 2000, only 12 such correlations held in 2006. However, only 10 in 2000 and 11 in 2006 of such strong to very strong trade relations may not have occurred by accident, with $p$-values of 0.05 or less. Overall, $33.3 \%$ and $36.7 \%$ of intra-African trade relations were strong to very strong and credible in 2000 and 2006, respectively. These findings suggest that after years of Africa's trade regionalism and NEPAD, decolonization of the meaning and function of state, REC and continental borders has not begun because intra-African trade relations have generally remained statistically insignificant and meaningless.

Analysis of the 2000 inter-RECs (including the ROA) exports matrix produced 7 (46.6\%) statistically significant export trade relations with $p$-values below 0.05 (see Table 2). On average, there are 5-in-a-100 odds that $46.6 \%$ of the 2000 inter-RECs exportation relations may have been strong to very strong by accident. These exportation relations include those of COMESA/ECCAS, COMESA/SADC, COMESA/ROA, ECCAS/ROA ECCAS/SADC ECCAS/ECOWAS, and SADC/ROA (see Table 2). But only COMESA exportations to SADC $(0.99304$ at $p$-value $<0.0001)$ and ECCAS's to the ROA (0.97854 at $p$-value of 0.0007) in 2000 constituted statistically very strong and credible intra-African trade relations. 
Table 2

Inter-REC Exports, 2000 \& 2006

\begin{tabular}{|c|c|c|c|c|c|c|c|c|}
\hline RECs & & & AMU & COMESA & ECCAS & ECOWAS & SADC & AFRICA \\
\hline \multirow{4}{*}{ AMU } & \multirow{2}{*}{2000} & Correlation & 1.00000 & 0.44618 & 0.54834 & 0.50425 & 0.37821 & 0.63502 \\
\hline & & $p$-value & & 0.3751 & 0.2599 & 0.3077 & 0.4597 & 0.1755 \\
\hline & \multirow{2}{*}{2006} & Correlation & 1.00000 & 0.58001 & 0.59284 & 0.51939 & 0.46660 & 0.86805 \\
\hline & & $p$-value & & 0.2275 & 0.2149 & 0.2910 & 0.3509 & 0.0250 \\
\hline \multirow{4}{*}{ COMESA } & \multirow{2}{*}{2000} & Correlation & & 1.00000 & 0.84395 & 0.41911 & 0.99304 & 0.88499 \\
\hline & & $p$-value & & & 0.0346 & 0.4081 & $<0.0001$ & 0.0191 \\
\hline & \multirow{2}{*}{2006} & Correlation & & 1.00000 & 0.87725 & 0.48241 & 0.97688 & 0.27294 \\
\hline & & $p$-value & & & 0.0217 & 0.3325 & 0.0008 & 0.6008 \\
\hline \multirow{4}{*}{ ECCAS } & \multirow{2}{*}{2000} & Correlation & & & 1.00000 & 0.81956 & 0.83524 & 0.97854 \\
\hline & & $p$-value & & & & 0.0459 & 0.0385 & 0.0007 \\
\hline & \multirow{2}{*}{2006} & Correlation & & & 1.00000 & 0.83228 & 0.91345 & 0.25460 \\
\hline & & $p$-value & & & & 0.0398 & 0.0109 & 0.6264 \\
\hline \multirow{4}{*}{ ECOWAS } & \multirow{2}{*}{2000} & Correlation & & & & 1.0000 & 0.41009 & 0.78323 \\
\hline & & $p$-value & & & & & 0.4194 & 0.0654 \\
\hline & \multirow{2}{*}{2006} & Correlation & & & & 1.00000 & 0.54633 & 0.26705 \\
\hline & & $p$-value & & & & & 0.2620 & 0.6089 \\
\hline \multirow{4}{*}{ SADC } & \multirow{2}{*}{2000} & Correlation & & & & & 1.00000 & 0.86579 \\
\hline & & $p$-value & & & & & & 0.0258 \\
\hline & \multirow{2}{*}{2006} & Correlation & & & & & 1.00000 & 0.16426 \\
\hline & & $p$-value & & & & & & 0.7558 \\
\hline \multirow{2}{*}{ AFRICA } & 2000 & $\begin{array}{l}\text { Correlation } \\
p \text {-value }\end{array}$ & & & & & & 1.00000 \\
\hline & 2006 & $\begin{array}{l}\text { Correlation } \\
p \text {-value }\end{array}$ & & & & & & 1.00000 \\
\hline
\end{tabular}

The 2006 inter-RECs export relations produced only 5 (33.3\%) trade correlations which were statistically significant at the confidence level of 0.05 or less (see Table 2). Evidently, the strength and significance of exportation relations of COMESA/ROA, ECCAS/ROA, and SADC/ROA declined between 2000 and 2006. Other than the attainment of increased strength and significance of the exportation relations of AMU to the ROA, those held by COMESA and ECCAS with the ROA deteriorated whilst the SADC/ROA exportation relations dropped from being strong in 2000 to carrying no meaning in 2006 (see Table 2). Simultaneously, the significance of exportations of COMESA/ECCAS, ECCAS/ECOWAS, and ECCAS/SADC increased marginally, whilst that of COMESA/SADC declined slightly between 2000 and 2006. Notwithstanding the marginal decline, COMESA/SADC exportation relations remained very strong and credible (0.97688 at $p$-values of 0.0008); and, ECCAS exportations to SADC were very strong and credible, too (0.91345 at $p$-value of 0.0109). An observation can be drawn that inter-RECs (including the ROA) exportation relations became generally statistically weaker, insignificant and less credible between 2000 and 2006.

In sharp contrast to the export relationships, there were only 3 (20\%) import trade correlations that were statistically significant, on the basis of a $p$-value of less than 0.05 in 2000 (see Table 3). These trade relations included COMESA imports from ROA and SADC, as well as SADC imports from ROA, which constitutes over $50 \%$ less than that for exportation relations found to be statistically significant in 2000. But only two of these intra-African importation relations were statistically very strong and credible; which are, COMESA's 
imports from the ROA (0.92190 at $p$-value of 0.0009$)$ and from SADC (0.95814 at $p$-value of 0.0026$)$. That is, whereas relatively more intra-Africa exportation relations were statistically significant and credible in 2000, imports trade correlations among them were almost all meaningless, except for three. It could mean that Africa's import relations with extra-continental sources were predominant in 2000.

Table 3

Inter-REC Imports, 2000 \& 2006

\begin{tabular}{|c|c|c|c|c|c|c|c|c|}
\hline RECs & & & AMU & COMESA & ECCAS & ECOWAS & SADC & AFRICA \\
\hline \multirow{4}{*}{ AMU } & \multirow{2}{*}{2000} & Correlation & 1.00000 & 0.41536 & 0.52513 & 0.48086 & 0.16880 & 0.53300 \\
\hline & & $p$-value & & 0.4128 & 0.2847 & 0.3343 & 0.7492 & 0.2762 \\
\hline & \multirow{2}{*}{2006} & Correlation & 1.00000 & 0.50724 & 0.56330 & 0.55244 & 0.35488 & 0.66888 \\
\hline & & $p$-value & & 0.3044 & 0.2444 & 0.2556 & 0.4900 & 0.1463 \\
\hline \multirow{4}{*}{ COMESA } & \multirow{2}{*}{2000} & Correlation & & 1.00000 & 0.69292 & 0.43771 & 0.95814 & 0.92190 \\
\hline & & $p$-value & & & 0.1270 & 0.3854 & 0.0026 & 0.0089 \\
\hline & \multirow{2}{*}{2006} & Correlation & & 1.00000 & 0.82787 & 0.45107 & 0.97641 & 0.90432 \\
\hline & & $p$-value & & & 0.0419 & 0.3693 & 0.0008 & 0.0133 \\
\hline \multirow{4}{*}{ ECCAS } & \multirow{2}{*}{2000} & Correlation & & & 1.00000 & 0.64612 & 0.55033 & 0.78506 \\
\hline & & $p$-value & & & & 0.1657 & 0.2578 & 0.643 \\
\hline & \multirow{2}{*}{2006} & Correlation & & & 1.00000 & 0.73897 & 0.83154 & 0.92436 \\
\hline & & $p$-value & & & & 0.0933 & 0.0402 & 0.0084 \\
\hline \multirow{4}{*}{ ECOWAS } & \multirow{2}{*}{2000} & Correlation & & & & 1.00000 & 0.29209 & 0.75029 \\
\hline & & $p$-value & & & & & 0.5743 & 0.0857 \\
\hline & \multirow{2}{*}{2006} & Correlation & & & & 1.00000 & 0.43525 & 0.78281 \\
\hline & & $p$-value & & & & & 0.3884 & 0.0656 \\
\hline \multirow{4}{*}{ SADC } & \multirow{2}{*}{2000} & Correlation & & & & & 1.00000 & 0.82641 \\
\hline & & $p$-value & & & & & & 0.0426 \\
\hline & \multirow{2}{*}{2006} & Correlation & & & & & 1.00000 & 0.86951 \\
\hline & & $p$-value & & & & & & 0.0244 \\
\hline \multirow{2}{*}{ AFRICA } & 2000 & $\begin{array}{l}\text { Correlation } \\
p \text {-value }\end{array}$ & & & & & & 1.00000 \\
\hline & 2006 & $\begin{array}{l}\text { Correlation } \\
p \text {-value }\end{array}$ & & & & & & 1.00000 \\
\hline
\end{tabular}

Generally, the 2006 inter-RECs importation relations increased and strengthened, relative to those in 2000 (see Table 3). From the 3 (20\%) of 2000, an additional three importation relations gained significance in 2006, increasing intra-African importation relations by almost $50 \%$ to $40 \%$. The new additions included COMESA's imports from ECCAS, and the latter's from SADC and the ROA. Whereas the 2000 importation of COMESA from SADC increased slightly in 2006, those from ROA declined marginally over the same period. SADC's importation relations from ROA increased slightly over the same period. But only three of the six importation relations were very strong and credible in 2006 (COMESA's imports from SADC and the ROA with correlations of 0.97641 at $p$-value of 0.0008 and 0.90432 at $p$-value of 0.0133 , respectively, as well as ECCAS imports from ROA with a correlation of 0.92436 at $p$-values of 0.0084 ). Whereas the statistical significance of inter-RECs (including the ROA) importations increased and strengthened in 2006, the trend needs to be read with caution in the context of increasing excessive Sino-Africa importation relations, especially since 2002. The occurrence of excessive importation from China must be blamed on NEPAD's pluralistic trade regionalism. Also, the general trend described in the statistics (see Tables 2 and 3) cannot be interpreted as a slowing down of vertical importation relations because NEPAD could have just created a situation wherein self-selecting states, due to their extra-continental trade relations, allowed some RECs to gain the status of conveyer belt for 
entry of extra-African imports.

The inter-RECs exportation relations between 2000 and 2006 provide statistical evidence of a general decline in three areas: the number of trading partners with statistically significant exportation relations; the strength of observed trade relations; and the credibility of such intra-African trade relations. Whereas in 2000 there were 8 exportation relations that were statistically high to very strong with correlation coefficient above 0.75, their number declined to 5 in 2006 (see Table 4). Between 2000 and 2006, exportation relations that were substantial and minor to moderate increased from 3 to 4 and 4 to 5, respectively, showing a general weakening of trade relations, whilst the SADC/ROA exportation relations dropped from strong to meaningless during the same period.

Table 4

Strength of RECs Trade Relations, 2000, Measured Through Correlation Coefficient

\begin{tabular}{|c|c|c|c|c|c|c|c|c|}
\hline \multirow{3}{*}{$\begin{array}{l}\text { Correlation } \\
\text { coefficient }\end{array}$} & \multicolumn{4}{|c|}{ RECs exportation relations } & \multicolumn{4}{|c|}{ RECs importation relations } \\
\hline & \multirow{2}{*}{2000} & \multirow{2}{*}{2006} & \multicolumn{2}{|c|}{ Number } & \multirow{2}{*}{2000} & \multirow{2}{*}{2006} & \multicolumn{2}{|c|}{ Number } \\
\hline & & & 2000 & 2006 & & & 2000 & 2006 \\
\hline $\begin{array}{l}\text { Below } 0.25 \\
\text { no meaningful } \\
\text { trade relations }\end{array}$ & & SADC-ROA & 0 & 1 & AMU-SADC & & 1 & 0 \\
\hline $\begin{array}{lr}\text { Between } & 0.25 \& \\
0.50 & \\
\text { minor } & \text { to } \\
\text { moderate } & \text { trade } \\
\text { relations } & \end{array}$ & $\begin{array}{l}\text { AMU-COMESA } \\
\text { AMU-SADC } \\
\text { COMESA-ECOWA } \\
\text { S } \\
\text { ECOWAS-SADC }\end{array}$ & \begin{tabular}{|l} 
AMU-SADC \\
COMESA-ECOW \\
AS \\
COMESA-ROA \\
ECCAS-ROA \\
ECOWAS-ROA \\
\end{tabular} & 4 & 5 & $\begin{array}{l}\text { AMU-COMESA } \\
\text { AMU-ECOWAS } \\
\text { COMESA-ECOW } \\
\text { AS } \\
\text { ECOWAS-SADC }\end{array}$ & $\begin{array}{l}\text { AMU-SADC } \\
\text { COMESA-ECOW } \\
\text { AS } \\
\text { ECOWAS-SADC }\end{array}$ & 4 & 3 \\
\hline $\begin{array}{l}\text { Between } 0.50 \& \\
0.75 \\
\text { substantial trade } \\
\text { relations }\end{array}$ & $\begin{array}{l}\text { AMU-ECCAS } \\
\text { AMU-ECOWAS } \\
\text { AMU-ROA }\end{array}$ & $\begin{array}{l}\text { AMU-COMESA } \\
\text { AMU-ECCAS } \\
\text { AMU-ECOWAS } \\
\text { ECOWAS-SADC }\end{array}$ & 3 & 4 & $\begin{array}{l}\text { AMU-ECCAS } \\
\text { AMU-ROA } \\
\text { COMESA-ECCAS } \\
\text { ECCAS-ECOWAS } \\
\text { ECCAS-SADC } \\
\end{array}$ & $\begin{array}{l}\text { AMU-COMESA } \\
\text { AMU-ECCAS } \\
\text { AMU-ECOWAS } \\
\text { AMU-ROA } \\
\text { ECCAS-ECOWAS } \\
\end{array}$ & 5 & 5 \\
\hline \begin{tabular}{|l|} 
Between $0.75 \&$ \\
0.90 \\
high level trade \\
relations
\end{tabular} & $\begin{array}{l}\text { COMESA-ECCAS } \\
\text { COMESA-ROA } \\
\text { ECCAS-ECOWAS } \\
\text { ECCAS-SADC } \\
\text { ECOWAS-ROA } \\
\text { SADC-ROA } \\
\end{array}$ & $\begin{array}{l}\text { AMU-ROA } \\
\text { COMESA-ECCAS } \\
\text { ECCAS-ECOWAS }\end{array}$ & 6 & 3 & $\begin{array}{l}\text { ECCAS-ROA } \\
\text { ECOWAS-ROA } \\
\text { SADC-ROA }\end{array}$ & $\begin{array}{l}\text { COMESA-ECCAS } \\
\text { ECCAS-SADC } \\
\text { ECOWAS-ROA } \\
\text { SADC-ROA }\end{array}$ & 3 & 4 \\
\hline $\begin{array}{l}\text { Above } 0.90 \\
\text { very strong } \\
\text { trade relations }\end{array}$ & $\begin{array}{l}\text { COMESA-SADC } \\
\text { ECCAS-ROA }\end{array}$ & $\begin{array}{l}\text { COMESA-SADC } \\
\text { ECCAS-SADC }\end{array}$ & 2 & 2 & $\begin{array}{l}\text { COMESA-SADC } \\
\text { COMESA-ROA }\end{array}$ & $\begin{array}{l}\text { COMESA-SADC } \\
\text { COMESA-ROA } \\
\text { ECCAS-ROA } \\
\end{array}$ & 2 & 3 \\
\hline
\end{tabular}

Conversely, the statistical analysis suggests that intra-Africa's importation relations has increased in number and strengthened in significance between 2000 and 2006. Whereas in 2000 only 5 importation relations were statistically strong to very strong with correlations above 0.75, the number increased to 7 in 2006 (see Table 4). The total number of importation relations which were minor to meaningless declined from 5 in 2000 to only 3 in 2006, at the same time as the AMU/SADC importation relations improved from being meaningless to being minor to moderate. On the edifice, this trend could suggest improvement in intra-African trade structures; however, optimism disappears when the origin of the imports being traded is traced. Apparently, some RECs have come to serve as bridges for their member states' extra-continental imports that become their exports to the ROA and other RECs under NEPAD (see Table 1). The converse of the strong to very strong exportations from some RECs and the ROA describes the importations by other RECs and, perhaps, many other states in the ROA. The dynamics involved in this regard are complex and they need to be analyzed 
separately in another paper. One key observation that can be made from the present statistical analyses, though, it is that no single African REC recorded a correlation in imports trade relations with other RECs and/or the ROA at a confidence level of less than 0.0001. Potentially, the continuance of Africa's vertical trade relations with former colonial powers and China could be aided by AU member states such as Angola, Ghana, Kenya, Nigeria, and South Africa and so on. To this extent, the colonial meaning and function of the RECs' and continental borders have not been decolonized; apparently, NEPAD trade regionalism enforces neo-colonization rather than decolonization.

\section{Conceptualization of Trade Regionalism for Africa's Decolonization-Bordering}

The potential for Africa's regionalism perpetuating neo-colonialism through the longstanding vertical trade relations with the former colonial powers is real (Bachmann \& Sidaway, 2010; Tsheola, 2010). The appeal of regionalism has been "geographically intuitive" because colonial bordering "created an extremely fragmented state system"; and, it has been understood and practiced as a mechanism for "the reconfiguration of neo-colonial influences and unfair trading practices” (Gibb, 2009, pp. 702, 703). Africa’s decolonization has been a taken-for-granted outcome of regionalism, which was the "founding principle" for the Organisation of African Unity (OAU), and has continued to be the primary rationale for the AU (Gibb, 2009; Ramutsindela, 2010b). Given that "a united Africa would not be a major economic force”, "by any reckoning” (Gibb, 2009, p. 703), vexed questions need to be asked regarding the interests that Africa's trade regionalism serves, as well as its decolonization impacts as a bordering and socio-spatial process. Such questions are crucial in the context that Africa's regionalism, which is synonymous with a litany of "unbroken failure" of regional integration record, continues to be justified on the basis of the economic rationale about the "smallness" of the states and "the benefits of scale economies" (Ilorah, 2008; Gibb, 2009), rather than on the requirement to transform the meaning and function of colonial borders, at the state, REC, and continental scales.

Insights into theorization of region-border nexus are instructive for the conceptualization of trade regionalism decolonization-bordering. If "the intended divisive nature of colonial boundaries should be counteracted by efforts to make the same boundaries integrative through commercial activities, development projects, and so forth" (Ramutsindela, 1999, p. 191), trade regionalism provides such an integrative recourse to infuse "new" decolonized meanings and functions to what would essentially remain colonial boundaries. Conception of space and power encapsulates the linkages between borders and regions, because borders' meaning and function are created and recreated as an "act of territorial power" (Newman, 2006; Paasi, 2009a, 2009b; Ramutsindela, 2011a). Bordering produces and reproduces dominion over territorial power created by the processes of inclusion and exclusion of what crosses versus that which is prevented from crossing (Newman \& Paasi, 1998; Yeung, 1998; Tauthail, 1999; Amin, 2004; Sassen, 2005; Newman, 2006; Agnew, 2007, 2008; Cunningham, 2009; Diener \& Hagen, 2009; Jones, 2009, 2010; Paasi, 2009a, 2009b; Parker \& Vaughan-Williams, 2009; Fall, 2010; O’Dowd, 2010; Jonas, 2011; Ramutsindela, 2011a). To this extent, borders shape, as they are shaped in return, by contents of spatiality they define and things whose interspatial relations, flows, and networks they govern (Newman \& Paasi, 1998; Yeung, 1998; Tauthail, 1999; Amin, 2004; Sassen, 2005; Newman, 2006; Agnew, 2007, 2008; Cunningham, 2009; Diener \& Hagen, 2009; Paasi, 2009a, 2009b; Parker \& Vaughan-Williams, 2009; Fall, 2010; Jones, 2009, 2010; O’Dowd, 2010; Jonas, 2011; Ramutsindela, 2011a).

Trade regionalism consists of "spatial forces" that create and recreate, construct and deconstruct space 
through bordering too (Newman, 2006; Paasi, 2009b; Fall, 2010; O’Dowd, 2010; Ramutsindela, 2011a); therefore, it should be deliberated in producing and reproducing "territorial power" for dominion over trade relations and governance of the regional spatiality. By definition, trade regionalism bordering should "create meanings of space” and "congeal (trade) flows into regional spatial forms” (Ramutsindela, 2011a, p. 3). However, caution should be exercised because of transforming the meaning and function of colonial borders, trade regionalism may in equal measure produce neo-colonization or decolonization.

\section{Conclusions}

This paper concludes that the predominance of vertical, rather than horizontal, trade relations with former colonial powers implies that the decolonization of Africa through trade regionalism has not begun. Confirming the persistence of the vertical trade relations, Gibb (2009, p. 713) observed that "almost without exception most African states trade more with the developed world, particularly Europe, than they do with each other”. Okoro and Oyewole (2011) arrived at a similar finding in regard to Africa's importations from China since the past decade. Africa's trade regionalism has failed to create meaningful "spaces of regionalism" over which RECs and the ROA could exercise dominion of "territorial power" of trade relations. For Africa's trade regionalism to render RECs and the ROA decolonization-bordering meaningful and functional for the specific objective of ensuring that RECs and Africa would gain dominion over "territorial power" so created, necessary discriminatory CET walls need to be installed in accordance with deliberate "time and space contingencies of bordering” in order that vertical importation relations with former colonial powers and China may not be excessive. The fundamental priority of creating spaces of regionalism cannot be the adoption of the MFN principle (Tsheola, 2010). Under NEPAD pluralistic trade relations, this principle of thumb will remain impossible at both the RECs and continental scales. NEPAD does not provide for decolonization-bordering at the RECs or AU scales; and, as a tool for Africa's trade regionalism it must be considered to have already failed (Simon, 2010; Tsheola, 2010).

This paper concludes that NEPAD pluralistic trade regionalism cannot extricate Africa from colonial trade-bordering imposture. It has failed to provide for a bordering process that recreates the meaning and function of colonial borders, as an act of reproducing territorial power over which Africa and its RECs could exercise dominion of trade relations in the interest of decolonization. It is important that research establishes how the constellations of African states in RECs and a unified continental territory could, through trade regionalism, counteract the borders' potential neo-colonization meaning and function as barriers to decolonization whilst simultaneously establishing reasonable regional bordering for the enforcement of amalgamated jurisdiction of effective CETs, without attracting the trade and investment wrath of the reactionary global forces? Such theorization could deal with at least two questions of: (1) what "new", perhaps "old”, meanings and functions does Africa's trade regionalism inscribe in the colonial borders? and (2) how does such inscription of the transformed meaning and function in the colonial borders impact on the prospects of decolonization?

\section{References}

Agnew, J. (2000). From the political economy of regions to regional political economy. Progress in Human Geography, 24, 101-110.

Agnew, J. (2007). No borders, no nations: Making Greece in Macedonia. Annals of the Association of American Geographers, 97, 398-422. 
Agnew, J. (2008). Borders on the mind: Re-framing border thinking. Ethics and Global Politics, 1, 175-191.

Allen, J., \& Cochrane, A. (2007). Beyond the territorial fix: Regional assemblages, politics and power. Regional Studies, 4, 1161-1175.

Amin, A. (2004). Regions unbounded: Towards a new politics of place. Geografiska Annaler, 86B, 33-44.

Anderson, J., \& O’Dowd, L. (1999). Borders, border regions and territoriality: Contradictory meanings, changing significance. Regional Studies, 33(7), 593-604.

Andoh, S. Y., Umezaki, M., Nakamura, K., Kizuki, M., \& Takano, T. (2006). Correlation between national income, HIV/AIDS and political status and mortalities in African countries. Public Health, 120, 624-633.

Austin, G. (2008). The "reversal of fortune" thesis and the compression of history: Perspectives from African and comparative economic history. Journal of International Development, 20, 996-1027.

Bachmann, V., \& Sidaway, J. D. (2010). African regional integration and European involvement: External agents in the East African Community. South African Geographical Journal, 92(1), 1-6.

Barber, G. M. (1988). Elementary statistics for geographers. London: The Guilford Press.

Bathelt, H. (2006). Geographies of production: Growth regimes in spatial perspective-Towards a relational view of economic action and policy. Progress in Human Geography, 30, 223-236.

Bayart, J-F. (2009). The state in Africa: The politics of the belly (2nd ed.). Cambridge: Polity Press.

Botha, P., \& Aggad, F. (2004). The Arab Magreb Union. In P. Hugo \& E. Maloka (Eds.), The state of Africa 2003-2004: A thematic and factual review (pp. 158-162). Pretoria: AISA.

Cunningham, H. (2009). Mobilities and enclosures after Seattle: Politicising borders in a "borderless world". Dialectical Anthropology, 33, 143-156.

Darling, J. (2010). A city of sanctuary: The relational re-imagining of Sheffield's asylum politics. Transactions of the Institute of British Geographers, 35, 125-140.

Davies, R. (1996). Promoting regional integration in Southern Africa: An analysis of prospects and problems from a South African perspective. African Security Review, 5(5), 27-38.

Diener, A., \& Hagen, J. (2009). Theorising borders in a "borderless world": Globalisation, territory and identity. Geography Compass, 3, 1196-1216.

Edbon, D. (1985). Statistics in geography (2nd ed.). Oxford: Blackwell.

Fall, J. (2010). Artificial states? On the enduring geographical myth of national borders. Political Geography, 29, 127-186.

Frankema, E. (2011). Colonial taxation and government spending in British Africa, 1880-1940: Maximizing revenue or minimizing effort? Explorations in Economic History, 48, 136-149.

Ghosh, B., \& De, P. (2005). Investigating the linkage between infrastructure and regional development in India: Era of planning to globalization. Journal of Asian Economics, 15, 1023-1050.

Gibb, R. (2009). Regional integration and Africa's development trajectory: Meta-theories, expectations and reality. Third World Quarterly, 30(4), 701-721.

Ginio, R., \& Schler, L. (2010). Decolonisation reconsidered: Rebirths, continuities and erasures. HAGAR, 9(2), 2-12.

Haring, L. L., \& Lounsbury, J. F. (1983). Introduction to scientific geographic research (3nd ed.). Dubuque: WMC Brown Company.

Hugo, P., \& Maloka, E. (Eds.). (2004). The state of Africa 2003-04: A thematic and factual review. Pretoria: AISA.

Ilorah, R. (2008). Trade, aid and national development in Africa. Development Southern Africa, 25, 83-98.

Imoto, S., Yabuuchi, Y., \& Watada, J. (2008). Fuzzy regression model of R \& D project evaluation. Applied Soft Computing, 8, 1266-1273.

Jones, M. (2009). Phase space: Geography, relational thinking, and beyond. Progress in Human Geography, 33(4), 487-506.

Jones, R. (2010). The spatiality of boundaries. Progress in Human Geography, 34, 263-267.

Jonas, A. E. G. (2011). Region and place: Regionalism in question. Progress in Human Geography, doi:10.1177/0309132510394118

Lautre, I. G., \& Fernandez, E. A. (2004). A methodology for measuring latent variables based on multiple factor analysis. Computational Statistics and Data Analysis, 45, 505-517.

Lefebvre, C. (2010). We have tailored Africa: French colonialism and the "artificiality” of Africa's borders in the interwar period. Journal Historical Geography, doi:10.1016/j.jhg.2010.11.004

Mackinnon, D., \& Tetzlaff, D. (2009). Conceptualizing scale in regional studies and catchment science: Towards an integrated characterization of spatial units. Geography Compass, 3, 976-996. 
Macleod, G., \& Jones, M. (2007). Territorial, scalar, networked, concerted: In what sense a "regional world”? Regional Studies, $41,1177-1191$.

Mainardi, S. (2003). Water availability and infrastructure development: Cross-country econometric and neural network estimates. Desalination, 158, 241-254.

Makgetlaneng, S. (2004). The Southern African Development Community. In P. Hugo \& E. Maloka (Eds.), The State of Africa 2003-04: A thematic and factual review (pp. 121-129). Pretoria: AISA.

Newman, D. (2006). The lines that continue to separate us: Borders in our "borderless world”. Progress in Human Geography, 30, 143-161.

Newman, D., \& Paasi, A. (1998). Fences and neighbours in the post-modern world: Boundary narratives in political geography. Progress in Human Geography, 22, 186-207.

Njinkeu, D., \& Fosso, B. P. (2006). Intra-African trade and regional integration. Retrieved from http://www.afdb.org/pls/portal/url/ITEM/22FF70E5AF17BA12E040C00AOC3D33E9

Noe, C. (2010). Spatiality and "borderlessness" in transfrontier conservation areas. South African Geographical Journal, 92(2), 144-159.

O’Dowd, L. (2010). From a "borderless world” to a "world of borders": "Bringing history back in”. Environment and Planning D, doi:10.1068/d2009

Okoro, E., \& Oyewole, P. (2011). A cost-benefit analysis of China's trade relations with sub-Saharan Africa. Chinese Business Review, 10(9), 734-743.

Olanrewaju, S. A. (2007). Aid for trade: Prospects for enhancing African trade capacity. Retrieved from http://www.afdb.org/pls/portal/url/ITEM/3DA174D19ADB3C0FE040C00A0C3D5277

Olivier, G. (2001). Regional integration and African revival. Africa Insight, 31(3), 39-46.

Overman, H. G., Rice, P., \& Venables, A. J. (2010). Economic linkages across space. Regional Studies, 44, 17-33.

Oyejide, T. A. (2000). Policies for regional integration in Africa. Economic Research Papers No. 62. Retrieved from http://www.afdb.org/pls/portal/url/ITEM/F5411BA3504F7686E030ABC0668C622B

Paasi, A. (1999). Boundaries as social practice and discourse: The Finish-Russian border. Regional Studies, 33, 669-680.

Paasi, A. (2004). Place and region: Looking through the prism of scale. Progress in Human Geography, 28, 536-546.

Paasi, A. (2005). Generations and the “development” of border studies. Geopolitics, 10, 663-671.

Paasi, A. (2009a). Bounded spaces in a 'borderless world': Border studies, power and the anatomy of territory. Journal of Power, 2, 213-234.

Paasi, A. (2009b). The resurgence of the "region" and "regional identity": Theoretical perspectives and empirical observations on regional dynamics in Europe. Review of International Studies, 35, 121-146.

Paasi, A. (2010). Commentary. Environment and Planning A, 42, 2296-2301.

Parket, N., \& Vaughan-Williams, N. (2009). Lines in the sand? Towards an agenda for critical border studies. Geopolitics, 14, 582-587.

Preece, R. (1994). Starting research: An introduction to academic research and dissertation writing. London: Pinter Publishers.

Ralinala, R. M. (2004). The Economic Community of West African States. In P. Hugo \& E. Maloka (Eds.), The state of Africa 2003-04: A thematic and factual review (pp. 130-134). Pretoria: AISA.

Ramutsindela, M. (1999). African boundaries and their interpreters. Geopolitics, 4(2), 180-198.

Ramutsindela, M. (2005). Perspectives on regionalism in (Southern) Africa. Geo Journal, 62, 107-110.

Ramutsindela, M. (2009). Gaddafi, continentalism and sovereignty in Africa. South African Geographical Journal, 91(1), 1-3.

Ramutsindela, M. (2010a). Africa’s borders in colonial and postcolonial contexts. HAGAR, 9(2), 13-29.

Ramutsindela, M. (2010b). Editorial: The SAGJ and 2010. South African Geographical Journal, 92(2), 91-95.

Ramutsindela, M. (2011a). Experienced regions and borders: The challenge for transactional approaches. Regional Studies, doi:10.1080/00343404.2011618121

Ramutsindela, M. (2011b). Southern Africa: The geopolitical configuration of lived regions. Political Geography, doi:1016/j.polgeo.2011.04.001

Samasuwo, N. (2004). The Community of Eastern and Southern African States. In P. Hugo \& E. Maloka (Eds.), The state of Africa 2003-04: A thematic and factual review (pp. 145-149). Pretoria: AISA.

Sassen, S. (2005). When national territory is home to the global: Older borders to novel borderings. New Political Economy, 10, 523-541. 
Sidaway, J. D. (2002). Imagined regional communities: Integration and sovereignty in the Global South. London: Routledge.

Simon, D. (2010). The changing context for regional integration in Southern Africa: How adaptive are its regional institutions? South African Geographical Journal, 92(2), 96-104.

Soderbaum, F., \& Taylor, I. (Eds.). (2008). Afro-Regions: The dynamics of cross-border micro-regionalism in Africa. Uppsala: Nordic Africa Institute.

Stambough, S. J., \& Thorson, G. R. (1999). Towards stability in presidential forecasting: The development of a multiple indicator model. International Journal of Forecasting, 15, 143-152.

Torokhti, A., \& Friedland, S. (2009). Towards theory of generic principal component analysis. Journal of Multivariate Analysis, 100, 661-669.

Tsheola, J. (2010). Global “openness” and trade regionalism of the new partnership for Africa's development. South African Geographical Journal, 92(1), 45-62.

Tuathail, G. (1999). Borderless worlds? Problematizing discourses of deterritorialisation. Geopolitics, 4, 139-154.

Weeks, J. (1996). Regional cooperation and Southern African development. Journal of Southern African Studies, 22(1), 99-117.

White, P. R., Tan, M. H., \& Hammond, J. K. (2006). Analysis of the maximum likelihood, total least squares and principal component approaches for frequency response function estimation. Journal of Sound and Vibration, 290, 676-689.

Yeung, H. (1998). Capital, state and space: Contesting the borderless world. Transactions of the Institute of British Geographers, 23, 291-309. 